\title{
Use of Adjuvant Endocrine Therapy in Postmenopausal Hormone Receptor-Positive Breast Cancer at German Breast Cancer Centers and University Hospitals - Results of an Enquiry (Adjuvant Endocrine Therapy Enquiry)
}

\author{
Thomas Kolben $^{\mathrm{a}}$ Susanne Engelmann ${ }^{\mathrm{b}}$ Susanne Maurer ${ }^{\mathrm{a}} \quad$ Martin Kolben $^{\mathrm{a}}$ \\ ${ }^{a}$ Frauenarztpraxis und Wolfart-Klinik Gräfelfing,

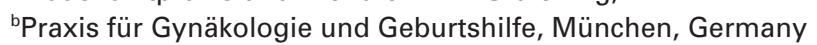

Keywords

Breast cancer - Endocrine therapy - Aromatase inhibitors

\section{Summary}

Background: Many studies about the adjuvant endocrine therapy of postmenopausal patients with hormone receptor-positive breast cancer have shown significant superiority of aromatase inhibitors (Als) compared to tamoxifen only. Within these studies, different Als (anastrozole, letrozole, exemestane) and treatment strategies (upfront, switch, extended adjuvant) were applied. Material and Methods: The intention of our enquiry was to evaluate the implementation of the results of these studies in German breast cancer centers and university hospitals. Questionnaires were sent to 200 breast cancer centers and university hospitals (returns: 108). Results: Our enquiry showed that most centers preferred anastrozole as upfront therapy in patients with an intermediate or high risk of relapse. Furthermore, during Al therapy, additional bisphosphonate treatment was applied 'always' in only $9 \%$ of cases, and in $78 \%$ of cases of proved osteopenia/osteoporosis. Surprisingly, 50\% of the participating centers do not exclude Als in premenopausal women. Conclusion: At the time of our enquiry, anastrozole as upfront therapy was consistent with the recommendations of the Arbeitsgemeinschaft Gynäkologische Onkologie (AGO) from 2009. Compared to tamoxifen, Als increase the risk of osteoporosis, which can, however, be prevented and treated with concomitant bisphosphonate therapy. The rare use of bisphosphonates as well as contraindicated Al therapy in premenopausal patients show amongst others the substantial need for more information.

\author{
Schlüsselwörter \\ Mammakarzinom • Endokrine Therapie · \\ Aromataseinhibitoren
}

\section{Zusammenfassung}

Hintergrund: Viele Studien zur adjuvanten endokrinen Behandlung des postmenopausalen Mammakarzinoms zeigten, dass der Einsatz von Aromataseinhibitoren (Al) gegenüber alleiniger Behandlung mit Tamoxifen die Ergebnisse signifikant verbessert. Im Rahmen der Studien kamen unterschiedliche Al (Anastrozol, Letrozol, Exemestan) und Therapieschemata (Upfront-, Switch-, erweiterte adjuvante Therapie) zum Einsatz. Material und Methoden: Ziel unserer Erhebung war es, die Umsetzung der Studienergebnisse hinsichtlich der Al-Therapie in deutschen Brustzentren und Universitätskliniken zu evaluieren. Dazu wurde ein Fragebogen erstellt, der an 200 Brustzentren und Universitätskliniken versendet wurde (Rücklauf: 108). Ergebnisse: Unsere Umfrage ergab, dass die meisten Zentren bei mittlerem und hohem Rezidivrisiko den Einsatz von Anastrozol im Rahmen einer Upfront-Therapie favorisieren und dass im Rahmen der Al-Therapie nur in $9 \%$ aller Fälle immer und in $78 \%$ bei nachgewiesener Osteopenie oder Osteoporose eine Bisphosphonat-Begleittherapie eingesetzt wird. Erstaunlicherweise schlossen 50\% der teilnehmenden Zentren bei prämenopausalen Patientinnen eine Al-Therapie nicht aus. Schlussfolgerung: Die Art der Anwendung von Al entsprach zum Zeitpunkt der Erhebung weitgehend den Empfehlungen der Arbeitsgemeinschaft Gynäkologische Onkologie (AGO) von 2009. Der eher sporadische Einsatz von Bisphosphonaten begleitend zu den Al, die im Vergleich zu Tamoxifen ein erhöhtes Osteoporoserisiko bewirken, und der prämenopausale Al-Einsatz trotz Kontraindikation zeigen, dass hier erheblicher Informationsbedarf besteht.

\footnotetext{
Prof. Dr. Martin Kolben

Praxis für Frauengesundheit und Wolfart-Klinik Gräfelfing

Bahnhofstrasse 9, 82166 Gräfelfing, Germany

Tel. +49 89 8986737-1, Fax -2

info@frauenarzt-graefelfing.de
}

\begin{tabular}{|c|c|c|}
\hline RGER & (C) 2012 S. Karger GmbH, Freiburg & Prof. Dr. Martin Kolben \\
\hline Fax +497614520714 & $1661-3791 / 12 / 0071-0039 \$ 38.00 / 0$ & $\begin{array}{l}\text { Praxis für Frauengesundheit und Wolfart-Klinik Gräfelfing } \\
\text { Bahnhofstrasse } 9,82166 \text { Gräfelfing, Germany }\end{array}$ \\
\hline $\begin{array}{l}\text { Information@Karger.de } \\
\text { www.karger.com }\end{array}$ & $\begin{array}{l}\text { Accessible online at: } \\
\text { www.karger.com/brc }\end{array}$ & $\begin{array}{l}\text { Tel. +49 } 89 \text { 8986737-1, Fax -2 } \\
\text { info@frauenarzt-graefelfing.de }\end{array}$ \\
\hline
\end{tabular}




\section{Introduction}

Breast cancer is the most common cancer entity in women. This disease ranks first in the causes of death related to cancer. Almost 58,000 women suffered from breast cancer in Germany in 2006, and around 17,300 women die every year from the sequelae of the disease [1]. In industrial nations, around $75 \%$ of breast cancer occurs in postmenopausal women, $80 \%$ present with hormone receptor-positive tumors [2]. For many years, treatment with tamoxifen $(20 \mathrm{mg}$ for 5 years) was considered as standard adjuvant endocrine therapy of postmenopausal, hormone receptor-positive breast cancer patients. Peto [3] showed in an analysis of 200,000 such patients that adjuvant antiestrogen therapy for 5 years significantly increases disease-free and overall survival independent of the lymph node status. A 15-year follow-up after 5 years of tamoxifen showed a reduction in the relative risk of relapse of $37 \%$ in nodal-positive patients and $43 \%$ in nodal-negative patients. A clear improvement of relapse-free survival (absolute $13.4 \%$, relative $33 \%$ ), as well as a $9 \%$ absolute decrease in breast cancer-related mortality, were demonstrated. An increase in mortality rate due to endometrial carcinomas or pulmonary embolisms of about $0.2 \%$ per decade was observed after 5 years of tamoxifen. Extended tamoxifen therapy over 10 years versus 5 years resulted in no advantages, as shown in the NSABP-14 study [4].

Several studies have demonstrated that aromatase inhibitors (AIs) are superior to tamoxifen, be it in upfront, sequential, or extended adjuvant therapy [5]. Therefore, the current recommendations for adjuvant therapy of postmenopausal patients with early hormone receptor-positive breast cancer include the use of an AI. Besides the non-steroidal AIs anastrozole and letrozole, the steroidal AI exemestane is used. Both classes of AI reduce the circulating estrogen level to $1-10 \%$. The clinical efficacy of the AIs of the 3rd generation can be explained by the reliable reduction of the peripheral estrogen levels and the thereby diminished availability of estrogen in the tumor tissue. AIs are usually applied in
3 treatment strategies: i) primary adjuvant use of an AI as an alternative to 5 years of tamoxifen immediately after the primary breast cancer therapy (upfront therapy); ii) primary use of an AI subsequent to a shortened tamoxifen therapy of 2-3 years until a total duration of therapy of 5 years is reached (sequential/switch therapy); iii) use of an AI after 5 years of adjuvant tamoxifen therapy in relapse-free patients (extended adjuvant therapy). A list of relevant studies is given in table 1 . It is not yet certain which treatment strategy is best and which conditions determine the use of the different AIs.

\section{Material and Methods}

\section{Questions}

In order to achieve an up-to-date overview of the situation in Germany regarding the adjuvant hormonal therapy in postmenopausal patients with early hormone receptor-positive breast cancer, we conducted the enquiry presented here. The goal of our enquiry was to find out how the results of the studies mentioned above are implemented in German breast cancer centers and university hospitals, and to investigate which AIs and treatment strategies are applied in relation to the risk of relapse (low, moderate, high) according to the St. Gallen-classification (table 2).

\section{Questionnaire}

A 2-sided questionnaire was sent to a total of 200 German breast cancer centers and university hospitals for the evaluation of our questions in April 2009. The questionnaire included 6 questions. In addition, a cover letter with instructions and an addressed envelope to preserve the anonymity of the respondent were attached.

\section{Statistical Analysis}

An entry mask for data collection and evaluation of the returned questionnaires was created in the program SPSS, version 17 (SPSS Inc., Chicago, IL, USA).

\section{Results}

\section{Response}

Of the 200 questionnaires sent to German breast cancer centers and university hospitals, 108 (54\%) were returned.

\begin{tabular}{llll}
\hline & Therapy & \\
\cline { 2 - 4 } & upfront & sequential/switch & extended adjuvant \\
\hline Trial [ref.] & ATAC [23], BIG 1-98 [24], & IES [14, 26], ARNO-95 [27, 28], & MA 17 [13], NSABP-B33 [33] \\
& TEAM [25] & ITA [29, 30], ABCSG-8 [31], & \\
& BIG 1-98 [15], TEAM [32] & \\
\hline
\end{tabular}

\begin{tabular}{lll}
\hline Relapse risk & & \\
\hline low & moderate & high \\
\hline pT $\leq 2 \mathrm{~cm}$, nodal negative, G 1, & $\mathrm{pT}>2 \mathrm{~cm}$, nodal negative, & nodal positive (1-3 LN metastases) and \\
no vessel invasion, Her-2/ & $\mathrm{G} 2-3$, peritumoral vessel & Her-2/neu-positive \\
neu-negative, age $\geq 35$ years & invasion, Her-2/neu-positive & or \\
& or & nodal positive with $\geq 4 \mathrm{LN}$ \\
& nodal positive (1-3 LN metastases) & \\
& and Her-2/neu-negative & \\
\hline
\end{tabular}

LN = Lymph node.
Table 1. Adjuvant endocrine therapy of postmenopausal hormone receptorpositive breast cancer - overview of trials

Table 2. Definitions of risk of relapse 

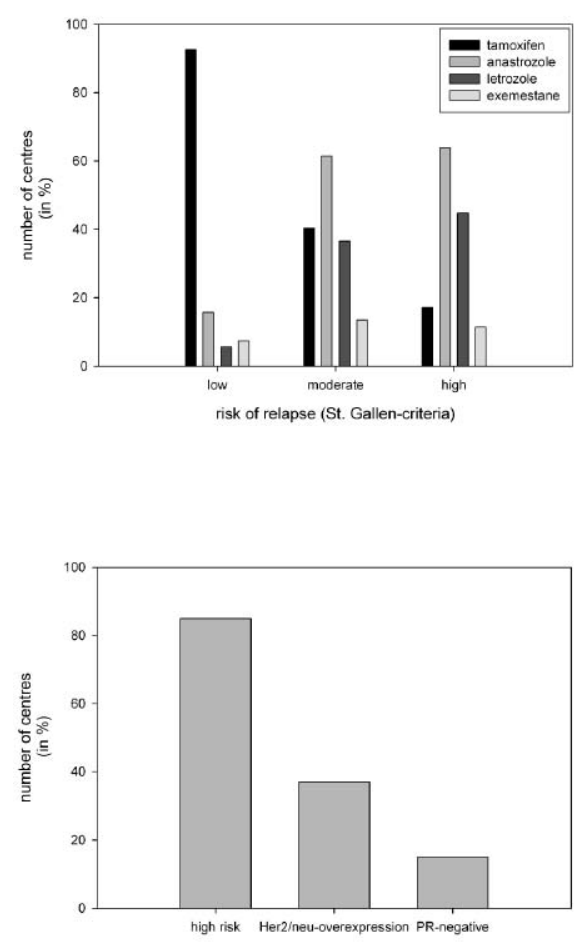

Fig. 1. Frequency of administration of drugs in postmenopausal breast cancer relative to the risk of relapse (multiple answers possible).

Fig. 3. Criteria for upfront therapy with an aromatase inhibitor (multiple answers possible; $\mathrm{PR}=$ progesterone receptor).
Fig. 2. Strategies of aromatase inhibitor use (upfront, switch, extended adjuvant (ext. adj.)) in postmenopausal breast cancer relative to the risk of relapse (multiple answers possible).

Fig. 4. Frequency of use of aromatase inhibitors (AIs) in the adjuvant therapy of premenopausal breast cancer.
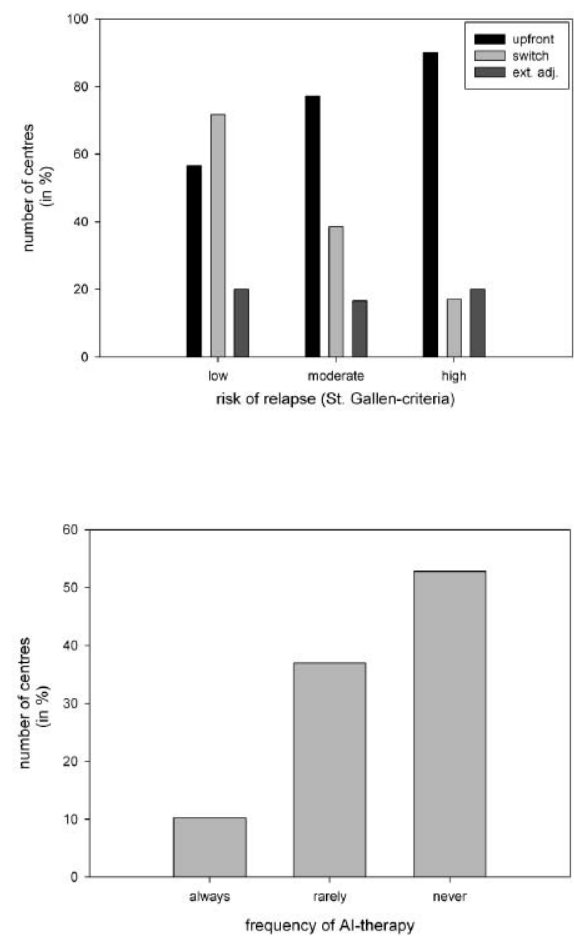

Postmenopausal Breast Cancer with Low Risk of Relapse

In German breast cancer centers, the use of tamoxifen was clearly preferred to AIs in the adjuvant endocrine therapy of postmenopausal breast cancer patients with low risk of relapse (table 2). Tamoxifen was named as the drug of choice in $93 \%$, anastrozole in $16 \%$, letrozole in $6 \%$, and exemestane in $7 \%$ (multiple answers possible) (fig. 1). In the case of ongoing tamoxifen therapy, $71 \%$ of the centers preferred a change to an AI which $72 \%$ of the centers would apply as sequential/ switch, $57 \%$ as upfront, and $20 \%$ as extended adjuvant therapy. Again multiple answers were possible (fig. 2).

Postmenopausal Breast Cancer with Moderate Risk of Relapse In the therapy of postmenopausal breast cancer with moderate risk of relapse (table 2), German breast cancer centers mostly used AIs: $62 \%$ anastrozole, $37 \%$ letrozole, and $14 \%$ exemestane. Only $40 \%$ used tamoxifen. Again multiple answers were possible (fig. 1). In the case of ongoing tamoxifen therapy in patients with moderate risk of relapse, $98 \%$ suggested a switch to an AI. The preferred treatment strategy was the upfront therapy (77\%), followed by sequential/switch therapy (39\%) and extended adjuvant therapy (17\%) (fig. 2). The centers frequently named multiple therapy options.

\section{Postmenopausal Breast Cancer with High Risk of Relapse}

In the treatment of postmenopausal breast cancer with high risk of relapse (table 2), AIs were also the preferred option
(64\% anastrozole, 45\% letrozole, 11\% exemestane). Only $17 \%$ indicated to use tamoxifen in this setting. Multiple answers were possible (fig. 1). In the case of ongoing tamoxifen therapy, $97 \%$ of the centers preferred a change to an AI. $90 \%$ marked upfront therapy, and $37 \%$ marked sequential/switch therapy or alternatively extended adjuvant therapy as the preferred option (fig. 2).

\section{Osteodensitometry and Addtional Bisphosphonates in AI Therapy}

Before starting AI therapy, $78 \%$ of the centers would perform an osteodensitometry, 22\% would not. Additionally to AI therapy, $9 \%$ of the centers give bisphosphonates 'always', $13 \%$ 'never', and $78 \%$ 'in the case of manifest osteoporosis, osteopenia, and risk of fractures'.

\section{Criteria for Use of AI}

A 'high risk of relapse' is regarded as a criterion for upfront AI therapy in $85 \%$. Her-2/neu overexpression and progesterone receptor negativity represent criteria for upfront AI use in 37 and $15 \%$ of cases, respectively (fig. 3 ).

\section{AI Therapy in Premenopausal Patients}

The question whether AIs also is used in the adjuvant therapy of premenopausal patients was answered by $10 \%$ of the centers with 'always', by $37 \%$ with 'rarely', and by $53 \%$ with 'never' (fig. 4). 


\section{Discussion}

The scale of the questionnaire had to be limited to the most important items regarding AI therapy in order to achieve a sufficient rate of return. In creating this questionnaire, we were aware of the limitations concerning the evaluation of the reasons for the use of different AIs in different settings. In postmenopausal breast cancer, the superiority of AIs compared to tamoxifen concerning the relapse-free and in some studies also the overall survival was clearly verified in the trials listed in table 1. Despite the fact that some authors propose specific AIs for the primary use in adjuvant therapy, no studies dealing with a head-to-head comparison of different AIs have been published to date. Therefore, guidelines on the use of specific AIs are lacking. The head-to-head comparison between letrozole and anstrozole in patients with early breast cancer and a high risk of relapse is currently investigated within the ongoing Femara Anastrozole Clinical Evaluation (FACE) trial. In patients with advanced breast cancer, however, a recent phase II study showed equal effects of exemestane compared to anastrozole [6]. In the neoadjuvant setting, another phase II study showed no differences between exemestane, letrozole, and anstrozole [7]. In our enquiry, the most commonly administered drug for postmenopausal breast cancer patients with low risk of relapse was tamoxifen (93\%), while the sequential or upfront use of AIs (particularly anastrozole followed by letrozole) was preferred in patients with moderate and high risk of relapse (62 and 64\%, respectively). Besides the missing guidelines for the use of specific AIs, the preferred choice of anastrozole and letrozole for upfront therapy can be explained by the fact that both substances are licensed for upfront use $[8,9]$. Exemestane is currently only licensed for sequential/switch therapy [10] (table 3). The most experience exists with anastrozole which the ATAC trial showed to provide the greatest benefit in patients undergoing upfront therapy. Follow-up data of 10 years are now available [11].

According to our enquiry about treatment strategies, a change to an AI was made 'always' in 71,98 , and $97 \%$ of patients with low, moderate, or high risk of relapse, respectively, even if a therapy with tamoxifen had already begun. This was remarkable particularly in patients with low risk, since a therapy with tamoxifen alone may have been sufficient in those cases.

In its 2010 guidelines, the Arbeitsgemeinschaft Gynäkologische Onkologie (AGO) placed the sequential/switch therapy for a duration of a total of 5 years at the highest level of recommendation with '++', upfront therapy was classified as '+'. Up to now, a survival benefit could only be confirmed in the sequential/switch studies (IES, ARNO-95, ABCSG-8), while proof of a survival benefit for upfront therapy is still lacking. An argument in favor of the sequential therapy is the potential development of resistance which could occur in the course of 5 years of adjuvant therapy with a single substance
Table 3. Approval for treatment strategies (2009)

\begin{tabular}{llll}
\hline & Therapy & & \\
\cline { 2 - 4 } & upfront & $\begin{array}{l}\text { sequential/ } \\
\text { switch }\end{array}$ & $\begin{array}{l}\text { extended } \\
\text { adjuvant }\end{array}$ \\
\hline Anastrozole & + & + & - \\
Letrozole & + & - & + \\
Exemestane & - & + & - \\
\hline
\end{tabular}

and which could affect the therapeutic success. The development of resistance under tamoxifen is examined well and can be avoided or at least postponed by the sequential use of the drug. In our enquiry, the majority of the centers chose a switch, especially in patients with early postmenopausal breast cancer and low risk of relapse (switch $72 \%$, upfront $57 \%$, extended adjuvant $20 \%$ ). Upfront therapy was favored by the majority of centers in breast cancer patients with a moderate or high risk of relapse (77 and $90 \%$, respectively). At the time of our enquiry, this was consistent with the 2009 AGO guidelines in which the upfront therapy was set at the highest level of recommendation ('++'). In the 2010 guidelines, however, 5-year sequential/switch therapy ranks highest and upfront therapy is classified as ' + '.

Our enquiry shows that at the beginning of an AI therapy, an osteodensitometry is carried out in only $78 \%$ of cases. At this point it should be mentioned that osteodensitometry in association with AI treatment is not usually covered by the public health insurance in Germany. The use of an AI is named as a reason for a bisphosphonate therapy in $9 \%$ of cases. $13 \%$ indicated no reason for a bisphosphonate therapy, and $78 \%$ used bisphosphonates only if a bone pathology existed (i.e. manifest osteoporosis, osteopenia, or risk of fractures). According to the recommendations from the 2007 St. Gallen conference, an osteodensitometry is to be initiated at the beginning of an AI treatment, and bisphosphonate therapy is to be applied if necessary according to the guidelines [12]. The risk of osteoporosis and bone fractures increases due to the reduction in peripheral estrogen caused by the AIs. The trials show that all AIs cause an increased risk of osteoporosis compared to tamoxifen, with only minor and insignificant differences between the single substances (letrozole $3.6 \%$ vs. placebo $2.9 \%$ [13], exemestane $3.1 \%$ vs. tamoxifen $2.3 \%$ [14], anastrozole $7.1 \%$ vs. tamoxifen $4.4 \%$ [2]). While all fractures have an impact on a patient's quality of life, only some have potentially life-threatening consequences. In the ATAC trial, the number of hip fractures in the anastrozole group was similar to the fracture rate in the tamoxifen group (16 vs. 20) [15]. In a recent study of 343 early breast cancer patients who were to receive AI therapy, Servitia et al. [16] showed that only 59 (17.7\%) had normal bone mineral density. In view of these numbers, it seems to be absolutely necessary to promote the use of osteodensitometry in breast cancer patients in Germany. In the 'ASCO Guidelines for Bisphosphonates', patients with early postmenopausal breast 
cancer, who receive AIs, are classified as belonging to the high-risk group for osteoporosis. For these patients, an osteodensitometry at the beginning of therapy is recommended as well as the use of bisphosphonates where necessary [5]. In the current AGO guidelines (2010), bisphosphonate treatment for the prevention and therapy of tumor therapyinduced osteoporosis is recommended most strongly (' ++ '). The recommendation of bisphosphonate therapy for the prevention of bone metastases in the adjuvant therapy of primary breast cancer obtained a '+'. In premenopausal patients receiving goserelin for ovarian suppression, Gnant et al. [17] showed improved disease-free survival in patients treated with anastrozole or tamoxifen by adding zoledronic acid. These results support the general recommendations for the prophylactic use of bisphosphonates in breast cancer patients receiving endocrine therapy. Another possible explanation for the benefit of bisphosphonate therapy is based on its supposed anticancer activity in both the pre- and postmenopausal adjuvant setting [18].

In our enquiry, we asked, in which case an upfront therapy with an AI is carried out routinely. High risk of relapse was named in $85 \%$, positive Her-2/neu status in $37 \%$, and progesterone receptor negativity in $15 \%$. At the 2007 St. Gallen conference, an extended adjuvant therapy with an AI was suggested for all patients with early hormone receptor-positive breast cancer and positive lymphatic nodes after 5 years of tamoxifen. The risk of relapse in patients with breast cancer reaches its maximum during the first 2 years after primary therapy. However, a small risk remains up to 15 years after the primary diagnosis. The average risk of relapse is $4.3 \%$ per year between the 5 th and the 12 th year after primary therapy. The most frequent events of relapse are distant metastases, followed by local relapse and axillary lymph node relapse [19]. The rates of relapse change corresponding to the time since the primary therapy, which should be considered when choosing an endocrine therapy. Patients with a high risk of relapse benefit more from an upfront therapy with an AI. Mauriac et al. [20] showed that letrozole appeared to provide a greater than average reduction in the risk of early relapse in patients with many involved lymph nodes, large tumors, and vascular invasion. Lin [21], however, is convinced that patients with a hormone receptor-positive tumor have an almost constant risk of relapse during the first 5-10 years after the primary diagnosis, while patients with a hormone receptornegative tumor only have an increased risk of relapse in the first years after the primary diagnosis. He concludes that an upfront therapy is not compulsory for patients with a hormone receptor-positive tumor [21].

Premenopausal status is still regarded as a contraindication for AI therapy. Another contraindication is chemotherapyinduced amenorrhea because the AI could stimulate the remaining ovarian function. The reduction of the peripheral estrogen levels leads to an increased central release of gonadotropins which could even provoke an ovulation [5]. If necessary, perimenopausal patients may receive a sequential therapy, if they are still amenorrheic after 2-3 years of tamoxifen treatment [22]. Up to now, the use of AIs in premenopausal women has been examined only within clinical trials using gonadotropin-releasing hormone analogues for ovarian suppression [17]. The fact that despite the guidelines and recommendations of the oncologic societies almost half of the participating centers use AIs in the adjuvant therapy of premenopausal breast cancer patients, shows amongst others that there is a substantial demand for more information regarding this aspect.

In summary, the German breast cancer centers perform adjuvant endocrine therapy of early postmenopausal breast cancer patients largely in accordance with current recommendations. However, there is a need for improvement concerning the additional use of bisphosphonates, and especially the surprisingly high use of AIs in premenopausal patients indicates a need for more information.

\section{Disclosure Statement}

None of the authors have been supported by or are in any economical relationship with any pharmaceutical companies.

\section{References}

1 Krebs in Deutschland 2005/2006: Häufigkeiten und Trends, 7. Ausgabe. Robert-Koch-Institut (Hrsg.) und die Gesellschaft der Epidemiologischen Krebsregister in Deutschland e. V. (Hrsg.). Berlin, 2010, pp. 56-9.

$\checkmark 2$ Arimidex, Tamoxifen, Alone or in Combination (ATAC) Trialists' Group, Forbes JF, Cuzick J, Buzdar A, Howell A, Tobias JS, Baum M: Effect of anastrozole and tamoxifen as adjuvant treatment for early-stage breast cancer: 100-month analysis of the ATAC trial. Lancet Oncol 2008;9:45-53.

3 Peto R, EBCTCG: Worldwide overview results, year 2000. Breast Cancer Res Treat 2000;64.

$\checkmark 4$ Fisher B, Dignam J, Bryant J, Wolmark N: Five versus more than five years of tamoxifen for lymph node-negative breast cancer: updated findings from the National Surgical Adjuvant Breast and Bowel Project B-14 randomized trial. J Natl Cancer Inst 2001;93:684-90.

5 Winer EP, Hudis C, Burstein HJ, Wolff AC, Pritchard KI, Ingle JN, Chlebowski RT, Gelber R, Edge SB, Gralow J, Cobleigh MA, Mamounas EP, Goldstein LJ, Whelan TJ, Powels TJ, Bryant J, Perkins C, Perotti J, Braun S, Langer AS, Browman GP, Somerfield MR: American Society of Clinical Oncology technology assessment on the use of aromatase inhibitors as adjuvant therapy for postmenopausal women with hormone receptorpositive breast cancer: status report 2004. J Clin Oncol 2005;23:619-29.

6 Llombart-Cussac A, Ruiz A, Antón A, Barnadas A, Antolín S, Alés-Martínez JE, Alvarez I, Andrés R,
García Saenz JA, Lao J, Carrasco E, Cámara C, Casas I, Martín M: Exemestane versus anastrozole as front-line endocrine therapy in postmenopausal patients with hormone receptor-positive, advanced breast cancer: final results from the Spanish Breast Cancer Group 2001-03 phase II randomized trial. Cancer 2012;118:241-7.

7 Ellis MJ, Suman VJ, Hoog J, Lin L, Snider J, Prat A, Parker JS, Luo J, DeSchryver K, Allred DC, Esserman LJ, Unzeitig GW, Margenthaler J, Babiera GV, Marcom PK, Guenther JM, Watson MA, Leitch M, Hunt K, Olson JA: Randomized phase II neoadjuvant comparison between letrozole, anastrozole, and exemestane for postmenopausal women with estrogen receptor-rich stage 2 to 3 breast cancer: clinical and 
biomarker outcomes and predictive value of the baseline PAM50-based intrinsic subtype ACOSOG Z1031. J Clin Oncol 2011;29:2342-9.

8 Fachinformation Arimidex ${ }^{\circledR}$, Stand April 2009.

9 Fachinformation Femara ${ }^{\circledR}$, Stand Juni 2009.

10 Fachinformation Aromasin ${ }^{\circledR}$, Stand Mai 2009.

11 Cuzick J, Sestak I, Baum M, Buzdar A, Howell A, Dowsett M, Forbes JF; ATAC/LATTE investigators: Effect of anastrozole and tamoxifen as adjuvant treatment for early-stage breast cancer: 10-year analysis of the ATAC trial. Lancet Oncol 2010;11:1135-41.

12 Jänicke F: The similarities of aromatase inhibitors outweigh the differences. Anticancer Drugs 2008;19:7-9.

13 Goss PE, Ingle JN, Martino S, Robert NJ, Muss HB, Piccart MJ, Castiglione M, Tu D, Shepherd LE, Pritchard KI, Livingston RB, Davidson NE, Norton L, Perez EA, Abrams JS, Therasse P, Palmer MJ, Pater JL: A randomized trial of letrozole in postmenopausal women after five years of tamoxifen therapy for early-stage breast cancer. N Engl J Med 2003;349:1793-802.

14 Coombes RC, Kilburn LS, Snowdon CF, Paridaens R, Coleman RE, Jones SE, Jassem J, Van de Velde CJ, Alvarez I, Del Mastro L, Ortmann O, Diedrich K, Coates AS, Bajetta E, Holmberg SB, Dodwell D, Mickiewicz E, Andersen J, Lønning PE, Cocconi G, Forbes J, Castiglione M, Stuart N, Stewart A, Fallowfield LJ, Bertelli G, Hall E, Bogle RG, Carpentieri M, Colajori E, Subar M, Ireland E, Bliss JM; Intergroup Exemestan Study: Survival and safety of exemestane versus tamoxifen after 2 years' tamoxifen treatment (Intergroup Exemestane Study): a randomised controlled trial. Lancet 2007:369:559-70.

15 Mouridsen HT, Giobbie-Hurder A, Mauriac L; for the BIG 1-98 Collaborative Group and International Breast Cancer Study Group Big 1-98: A randomized double-blind phase III study evaluating letrozole and tamoxifen given in sequence as adjuvant endocrine therapy for postmenopausal women with receptor-positive breast cancer. SABCS 2008; abstr 13 .

16 Servitja S, Nogués X, Prieto-Alhambra D, Martínez-García M, Garrigós L, Peña MJ, de Ramon M, Díez-Pérez A, Albanell J, Tusquets I: Bone health in a prospective cohort of postmenopausal women receiving aromatase inhibitors for early breast cancer. Breast 2011;Epub ahead of print.

17 Gnant M, Mlineritsch B, Stoeger H, LuschinEbengreuth G, Heck D, Menzel C, Jakesz R, Seifert M, Hubalek M, Pristauz G, Bauernhofer T, Eidtmann H, Eiermann W, Steger G, Kwasny W,
Dubsky P, Hochreiner G, Forsthuber EP, Fesl C, Greil R; Austrian Breast and Colorectal Cancer Study Group, Vienna, Austria: Adjuvant endocrine therapy plus zoledronic acid in premenopausal women with early-stage breast cancer: 62-month follow-up from the ABCSG-12 randomised trial. Lancet Oncol 2011;12:631-41.

18 Diel IJ, Solomayer EF, Costa SD, Gollan C, Goerner R, Wallwiener D, Kaufmann M, Bastert G: Reduction in new metastases in breast cancer with adjuvant clodronate treatment. $\mathrm{N}$ Engl J Med 1998;339:357-63.

19 Tusquets I, de Bes T, Tormo SS, Mestres JA: Start strong or switch? Adjuvant endocrine strategies for postmenopausal women with hormone-sensitive breast cancer. Biomed Pharmacother 2009;63:1-10.

20 Mauriac L, Keshaviah A, Debled M, Mouridsen H, Forbes JF, Thürlimann B, Paridaens R, Monnier A, Láng I, Wardley A, Nogaret JM, Gelber RD, Castiglione-Gertsch M, Price KN, Coates AS, Smith I, Viale G, Rabaglio M, Zabaznyi N, Goldhirsch A; BIG 1-98 Collaborative Group; International Breast Cancer Study Group: Predictors of early relapse in postmenopausal women with hormone receptor-positive breast cancer in the BIG 1-98 trial. Ann Oncol 2007;18:859-67.

21 Lin UN, Winer EP: Advances in adjuvant endocrine therapy for postmenopausal women. J Clin Oncol 2008;26:798-805.

22 Harbeck N: IES - Größere Überlebenschance bei Brustkrebs durch Switch auf Exemestan. Frauenarzt 2008;49:396-98.

23 Howell A, Cuzick J, Baum M, Buzdar A, Dowsett M, Forbes JF, Hoctin-Boes G, Houghton J, Locker GY, Tobias JS, ATAC Trialists' Group: Results of the ATAC (Arimidex, Tamoxifen, Alone or in Combination) trial after completion of 5 years adjuvant treatment for breast cancer. Lancet 2005;365:60-2.

24 Breast International Group (BIG) 1-98 Collaborative Group, Thürlimann B, Keshaviah A, Coates AS, Mouridsen H, Mauriac L, Forbes JF, Paridaens R, Castiglione-Gertsch M, Gelber RD, Rabaglio M, Smith I, Wardley A, Price KN, Goldhirsch A: A comparison of letrozole and tamoxifen in postmenopausal women with early breast cancer. N Engl J Med 2005;353:2747-57.

25 Jones SE, Seynaeve C, Hasenburg A: Results of the first planned analysis of the TEAM (tamoxifen exemestane adjuvant multinational) prospective randomized phase III trial in hormone sensitive postmenopausal early breast cancer. SABCS 2008; abstr 15.

26 Coombes RC, Hall E, Gibson LJ, Paridaens R, Jassem J, Delozier T, Jones SE, Alvarez I, Bertelli G, Ortmann O, Coates AS, Bajetta E,
Dodwell D, Coleman RE, Fallowfield LJ, Mickiewicz E, Andersen J, Lønning PE, Cocconi G, Stewart A, Stuart N, Snowdon CF, Carpentieri M Massimini G, Bliss JM, van de Velde C; Intergroup Exemestane Study: A randomized trial of exemestane after two to three years of tamoxifen therapy in postmenopausal women with primary breast cancer. N Engl J Med 2004;350:1081-92.

27 Jakesz R, Jonat W, Gnant M, Mittlboeck M, Greil R, Tausch C, Hilfrich J, Kwasny W, Menzel C, Samonigg H, Seifert M, Gademann G, Kaufmann M; on behalf of the ABCSG and the GABG: Switching of postmenopausal women with endocrine-responsive early breast cancer to anastrozole after 2 years adjuvant tamoxifen: combined results of ABCSG trial 8 and ARNO 95 trial. Lancet 2005;366:455-62.

28 Kaufmann M, Jonat W, Hilfrich J, Eidtmann H, Gademann G, Zuna U, von Minckwitz G: Improved overall survival in postmenopausal women with early breast cancer after anastrozole initiated after treatment with tamoxifen compared with continued tamoxifen: the ARNO-95 Study. J Clin Oncol 2007;25:2664-70.

29 Boccardo F, Rubagotti A, Aldrighetti D, Buzzo F, Cruciani G, Farris A, Mustacchi G, Porpiglia M, Schieppati G, Sismondi P: Switching to an aromatase inhibitor provides mortality benefit in early breast carcinoma-pooled analysis of 2 consecutive trials. American Cancer Society, 2007; published online at www.interscience.wiley.com.

30 Boccardo F, Rubagotti A, Puntoni M, Guglielmini P, Amoroso D, Fini A, Paladini G, Mesiti M, Romeo D, Rinaldini M, Scali S, Porpiglia M, Benedetto C, Restuccia N, Buzzi F, Franchi R, Massidda B, Distante V, Amadori D, Sismondi P: Switching to anastrozole versus continued tamoxifen treatment of early breast cancer: preliminary results of the Tamoxifen Anastrozole trial. J Clin Oncol 2005;23:5138-47.

31 Jakesz R, Gnant M, Griel R: Tamoxifen and anastrozole as a sequencing strategy in postmenopausal women with hormone-responsive early breast cancer: updated data from the Austrian Breast and Colorectal Cancer Study Group Trial 8. SABCS 2008;abstr 14.

32 Rea D: Five years of exemestane as initial therapy compared to five years of tamoxifen followed by exemestane: the TEAM trial, a prospective, randomized, phase III trial in postmenopausal women with hormone-sensitive early breast cancer. SABCS 2009; abstr 11.

33 Mamounas EP: Adjuvant exemestane therapy after 5 years of tamoxifen: rationale for the NSABP-B33 trial. Oncology 2001;15(5 suppl 7):35-9. 